\title{
Microstructure and mechanical properties of
}

\section{Mg-Zn-Y alloy sheet prepared by hot-rolling}

\section{T. Itoi ${ }^{\mathrm{a}}$, T. Inazawa ${ }^{\mathrm{a}}$, M. Yamasaki ${ }^{\mathrm{b}}$, Y. Kawamura ${ }^{\mathrm{b}}$ and}

\section{Hirohashi ${ }^{\text {a }}$}

${ }^{a}$ Department of Mechanical Engineering, Chiba University, Chiba 263-8522, Japan.

${ }^{b}$ Department of Materials Science and Engineering, Kumamoto University, Kumamoto 860-8555, Japan.

Corresponding author. Tel.: +81-43-290-3199; Fax: +81-43-290-3039;

e-mail: itoi@faculty.chiba-u.jp

\begin{abstract}
In this study, the microstructure and mechanical properties of $\mathrm{Mg}-\mathrm{Zn}-\mathrm{Y}$ alloy sheets were investigated. Tensile tests at room temperature were performed along the rolling direction of $\mathrm{Mg}_{98} \mathrm{Zn}_{1} \mathrm{Y}_{1^{-}}, \mathrm{Mg}_{96} \mathrm{Zn}_{2} \mathrm{Y}_{2^{-}}$, and $\mathrm{Mg}_{94} \mathrm{Zn}_{3} \mathrm{Y}_{3^{-}}$alloy sheets and their annealed states $(773 \mathrm{~K}$ for $0.6 \mathrm{ks})$. These alloy sheets exhibited yield strengths of 261,317 , and $380 \mathrm{MPa}$, and
\end{abstract}


elongations of 12, 10, and $6 \%$, respectively. The yield strength of a Mg-Zn-Y alloy sheet with Zn and Y contents greater than 2 at.\% was higher than 300 $\mathrm{MPa}$. The microstructure observations suggested that the alloy sheet strength mainly resulted from (i) the formation of basal texture in the long period stacking ordered (LPSO) phase and (ii) the uniform dispersion of a fine $\mathrm{Mg}_{3} \mathrm{Zn}_{3} \mathrm{Y}_{2}$ phase. In the annealed state, the yield strength tended to decrease, while the elongation tended to increase. Large elongations of $20 \%$ or more were achieved in the $\mathrm{Mg}_{98} \mathrm{Zn}_{1} \mathrm{Y}_{1-}$ and $\mathrm{Mg}_{96} \mathrm{Zn}_{2} \mathrm{Y}_{2}$-alloy annealed sheets. The cold workability of the $\mathrm{Mg}-\mathrm{Zn}-\mathrm{Y}$ alloy sheets and an AZ31-O sheet were evaluated, using a V-bending test at room temperature. Both $\mathrm{Mg}_{98} \mathrm{Zn}_{1} \mathrm{Y}_{1^{-}}$and $\mathrm{Mg}_{96} \mathrm{Zn}_{2} \mathrm{Y}_{2^{-}}$annealed sheets could be bent without cracking with a minimum bending radius per thickness of 3.3, which was less than that of the AZ31-O sheet. Texture randomization occurred in the Mg-Zn-Y alloy annealed sheets owing to re-crystallization of the $\mathrm{Mg}$ phase, which was confirmed by electron backscattering diffraction (EBSD) analysis. Large elongations and good cold workability of the Mg-Zn-Y annealed sheets are presumably attributed to an increase in the randomness of the $\mathrm{Mg}$ phase owing to re-crystallization. These results suggested that a Mg alloy sheet of high yield strength or good 
cold workability could be prepared by controlling the alloy composition and its microstructure in the Mg-Zn-Y alloy system.

Keywords: Mg alloy, Hot-rolling, Long period stacking ordered (LPSO) phase, Mechanical Properties.

\section{Introduction}

The density of magnesium is $1.79 \mathrm{~g} / \mathrm{cm}^{3}$, which is approximately two-thirds that of aluminum and one-fourth that of steel. Thus, magnesium is suitable for lightweight structural materials. The use of such materials would reduce the weight of transportation vehicles, such as cars and airplanes, and reduce carbon dioxide emissions. In 2001, a rapidly solidified powder/metallurgy (RS P/M) $\mathrm{Mg}_{97} \mathrm{Zn}_{1} \mathrm{Y}_{2}\left(\right.$ at.\%) alloy of yield strength $\left(\sigma_{\mathrm{y}}\right)$ higher than $600 \mathrm{MPa}$ and elongation $(\delta)$ of $5 \%$ at room temperature has been developed. The mechanism behind the strength of the RS P/M Mg alloy presumably depends on a grain refinement of approximately $200 \mathrm{~nm}$ and the long period stacking ordered (LPSO) phase formed in each Mg grain [1,2]. Thereafter, both 18R- and 14H-type LPSO phases are recognized as stable 
phases in the Mg-Zn-Y alloy system. In addition, various $14 \mathrm{H}-, 18 \mathrm{R}-, 10 \mathrm{H}-$, and 24R-type- LPSO structures in Mg-TM-Y (TM=Zn, Cu, or Ni) alloys and their annealed states have been discovered [3-6]. Abe et al. characterized their unique structure, using the atomic resolution high angle annular dark field (HAADF)-STEM technique [3]. The LPSO phase exhibits a chemically ordered long-period structure in which $\mathrm{Zn}$ and/or $\mathrm{Y}$ atoms are segregated into two atomic layers adjacent to the defect of the layer. The chemically ordered $\mathrm{Zn}$ and $\mathrm{Y}$ elements in the adjacent layers were also evidenced, using a 3 dimensional atom probe (3DAP) [7]. Recently, an 18R-type LPSO phase was also found in the $\mathrm{Mg}-\mathrm{Gd}-\mathrm{Al}$ system and the structure was characterized by the HAADF-STEM technique $[8,9]$. These reports clearly showed that the Gd atoms in the LPSO phase were located in four consecutive planes of six closed packed planes instead of two layers, as proposed for the LPSO phase in the $\mathrm{Mg}-\mathrm{Zn}-\mathrm{Y}$ alloy. A recent study confirmed that this feature was also present in the LPSO phase formed in Mg-Zn-RE (RE: Y or Er) systems [10]. The LPSO structure combines a long period chemical-order with a stacking-order. This synchronized LPSO structure interests structural analysts and researchers devoted to the development of high strength $\mathrm{Mg}$ alloys [11]. 
Recently, Mg alloys with yield strengths greater than $300 \mathrm{MPa}$ have been developed in the Mg-TM-Y (TM=Zn, Cu, or Ni) alloy system [12,13]. For instance, the extruded $\mathrm{Mg}_{97} \mathrm{Cu}_{1} \mathrm{Y}_{2}$ alloy containing the LPSO phase exhibited high $\sigma_{\mathrm{y}}$ of $297 \mathrm{MPa}$ and a reasonable $\delta$ of $8 \%$ at room temperature and also exhibited $\sigma_{\mathrm{y}}$ greater than $250 \mathrm{MPa}$ at $473 \mathrm{~K}$ [12]. Hot-extrusion is an effective technique for improving the mechanical properties of $\mathrm{Mg}$ alloys containing the LPSO phase. Yamasaki et al. reported that the presence of the LPSO phase in a Mg-Zn-Y alloy lead to refinement the $\mathrm{Mg}$ grains by dynamic re-crystallization, which is caused by strain-induced hot-extrusion resulting in the deformation of the LPSO phase. The re-crystallized Mg grains with weak texture improve the ductility and dispersion of the fiber-shaped LPSO phase and contribute to the strengthening of the extruded Mg-Zn-Y alloy [14]. Furthermore, high-strength $\mathrm{Mg}$ alloy sheets are developed in $\mathrm{Mg}-\mathrm{Ni}-\mathrm{Y}$ alloy, using the LPSO phase. The $\sigma_{\mathrm{y}}$ of the $\mathrm{Mg}_{90.5} \mathrm{Ni}_{3.25} \mathrm{Y}_{6.25}$ (at.\%) alloy sheet was higher than $450 \mathrm{MPa}$, and the $\delta$ was $8 \%$ at room temperature [15]. The strength of this alloy sheet was significantly high, which is presumably attributed to the high volume fraction of the LPSO phase. Therefore, controlling the alloy composition and its microstructure are important in the 
preparation of a Mg alloy sheet of high strength, large elongation, and good cold workability in the Mg-Zn-Y alloy system. However, studies on the microstructure and mechanical properties of $\mathrm{Mg}$ alloy sheets containing the LPSO phase fabricated by rolling process are few. Moreover, investigations of the cold workability of $\mathrm{Mg}$ sheets strengthened by the presence of the LPSO phase are extremely limited [16]. Evaluation of the secondary workability of $\mathrm{Mg}$ alloy sheets at room temperature is important for practical applications.

This paper reports on the microstructure, tensile properties and cold workability of Mg-Zn-Y alloy sheets and their annealed state. Their mechanical properties and cold workability are compared with those of commercial $\mathrm{Mg}$ alloy (AZ 31) sheet.

\section{Experimental Procedure}

Alloy ingots composed of $\mathrm{Mg}_{98} \mathrm{Zn}_{1} \mathrm{Y}_{1}, \mathrm{Mg}_{96} \mathrm{Zn}_{2} \mathrm{Y}_{2}$, and $\mathrm{Mg}_{94} \mathrm{Zn}_{3} \mathrm{Y}_{3}$ (at.\%) were prepared by furnace melting of high-purity $\mathrm{Mg}, \mathrm{Zn}$, and $\mathrm{Y}$ in an iron-crucible under a $\mathrm{CO}_{2}$ atmosphere and casting them into a steel die (20 $\times 30 \times 70 \mathrm{~mm}^{3}$ ). The cast ingots were re-melted in an iron-crucible at 
approximately $1113 \mathrm{~K}$ and cast into a water-cooled $\mathrm{Cu}$ mold $(5 \times 15 \times 100$ $\mathrm{mm}^{3}$ ) to avoid segregation of solute elements by rapid solidification. The compositions of these cast alloys were evaluated using X-ray fluorescence analysis (XRF:JSX-3100R II ) and were determined to be Mg-1.2Zn-1.1Y $(\mathrm{Cu}<0.1)$ at.\% for $\mathrm{Mg}_{98} \mathrm{Zn}_{1} \mathrm{Y}_{1}$ cast alloy, $\mathrm{Mg}-2.2 \mathrm{Zn}-1.9 \mathrm{Y}(\mathrm{Cu}<0.1)$ at.\% for $\mathrm{Mg}_{96} \mathrm{Zn}_{2} \mathrm{Y}_{2}$ cast alloy and $\mathrm{Mg}-3.1 \mathrm{Zn}-3.1 \mathrm{Y}(\mathrm{Cu}<0.1)$ at.\% for $\mathrm{Mg}_{94} \mathrm{Zn}_{3} \mathrm{Y}_{3}$ cast alloy, respectively. These cast alloys included $\mathrm{Cu}$ with less than 0.1 at $\%$ as a contamination. These cast alloys were contaminated by $\mathrm{Cu}$ without intending it when the alloy was melted in the crucible which was used for various alloys melt.

Next, the cast alloys were rolled at $693 \mathrm{~K}$ in air to achieve a $90 \%$ thickness reduction. The rolled sheets were annealed at $773 \mathrm{~K}$ for $0.6 \mathrm{ks}$. A tensile test was performed three times at room temperature for each specimen. The yield strength and elongation were evaluated by averaging the measured values. The microstructures were examined using a scanning electron microscope (SEM; JSM-5300LV) and a transmission electron microscope (TEM; JEM-2100F). The basal plane pole figure was measured up to 60 degrees using the Schultz reflection method with an X-ray diffractometer 
(XRD; JDX3530). The grain orientation was examined using electron backscattering diffraction (EBSD) equipped to an SEM (JEM-7001F). The cold workability was estimated by a 90 -degree V-bending test. The V-bending test was performed at a cross-head speed of $0.83 \mathrm{~mm} / \mathrm{s}$ at room temperature. A schematic of the V-bending test with accompanying dimensions is shown in Fig. 1. The minimum bending radii per thickness $R / t$ for various radii (where $\mathrm{R}$ is the tip punch radius, and $t$ is the sheet thickness) are shown in Table 1. The V-bending limit was checked with visual inspection and also confirmed, using the SEM. The cold workability of the Mg-Zn-Y sheets were compared with that of an AZ31-O sheet (annealed at $573 \mathrm{~K}$ for $1.8 \mathrm{ks}$ ).

\section{Results and discussions}

\subsection{Microstructure and mechanical properties of $\mathrm{Mg}-\mathrm{Zn}-\mathrm{Y}$ cast alloys}

Figure 2 shows the SEM backscatter electron images (BEIs) of (a) $\mathrm{Mg}_{98} \mathrm{Zn}_{1} \mathrm{Y}_{1^{-}}$, (b) $\mathrm{Mg}_{96} \mathrm{Zn}_{2} \mathrm{Y}_{2^{-}}$, and (c) $\mathrm{Mg}_{94} \mathrm{Zn}_{3} \mathrm{Y}_{3^{-}}$cast alloys. The black and gray contrasts correspond to the Mg- and LPSO- phases, respectively. Furthermore, as indicated by white circles in Figs. 2 (a), (b), and (c), brighter contrast phases of 1 to $5 \mu \mathrm{m}$ are observed at grain boundaries. The XRD 
results indicate that these cast alloys consist of Mg-, LPSO-, and $\mathrm{Mg}_{3} \mathrm{Zn}_{3} \mathrm{Y}_{2^{-}}$ phases. Thus, brighter contrasts correspond to the $\mathrm{Mg}_{3} \mathrm{Zn}_{3} \mathrm{Y}_{2}$ phase. Therefore, these cast alloys consist of three phases. The estimated fractions in each images corresponding to the $\mathrm{Mg}$ phase are $84 \%$ for Fig. 2 (a), 70\% for Fig. 2 (b), and $57 \%$ for Fig. 2 (c). These results indicate that the $\mathrm{Mg}$ phase decreases with increasing solute element content in the composition. The Vickers hardness values are 58HV0.5, 70HV0.5, and 85HV0.5 for $\mathrm{Mg}_{98} \mathrm{Zn}_{1} \mathrm{Y}_{1}$-, $\mathrm{Mg}_{96} \mathrm{Zn}_{2} \mathrm{Y}_{2}$-, and $\mathrm{Mg}_{94} \mathrm{Zn}_{3} \mathrm{Y}_{3}$-cast alloys, respectively. Thus, the LPSO- and $\mathrm{Mg}_{3} \mathrm{Zn}_{3} \mathrm{Y}_{2^{-}}$phases apparently contribute to the increase in hardness.

Figure 3 shows (a) electron diffraction (ED) pattern, (b) high resolution TEM (HRTEM) image and (c) HAADF-STEM image of the LPSO phase. In Fig.3 (a), the arrow-head indicates the extra reflection spot at the positions of $n / 6$ (0002) hcp (where $n$ is an integer). In addition, as shown in the ED pattern, the (30-30) is perpendicular to the c-axis. Therefore, the LPSO phase is an 18R-type LPSO structure. The stacking sequence of the LPSO structure is ABABABCACACABCBCBCA with a period of $4.86 \mathrm{~nm}$ along the c-axis as shown by the HRTEM image in Fig. 3 (b). Figure 3 (c) 
shows atom resolution HAADF-STEM image of the LPSO structure. Because the $\mathrm{Z}$ numbers of the $\mathrm{Y}(\# 39)$ and $\mathrm{Zn}$ (\#30) atoms are higher than that of the $\mathrm{Mg}(\# 12)$ atom, the bright and dark dots in the image correspond to $\mathrm{Y}, \mathrm{Zn}$, and $\mathrm{Mg}$ atoms, respectively. The HAADF-STEM image clearly shows that both solute elements of $\mathrm{Zn}$ and/or $\mathrm{Y}$ are enriched in the stacking layers of $\mathrm{ABCA}, \mathrm{CABC}$, and $\mathrm{BCAB}$, as recognized from the four brighter layers indicated by the white lines in Fig.3 (c). Consequently, the LPSO structure is not composed of a simple polymorphic structure with periodically introduced layered defects. Instead, it is composed of solute elements that are enriched in four-atom layers adjacent to the layered defect, resulting in a chemically ordered structure. These results suggest that the grain boundary phase with gray contrast, as shown in Figs. 2 (a), (b), and (c) is the 18R-type LPSO phase, which is known as the stable phase of $\mathrm{Mg}_{12} \mathrm{ZnY}$ in the Mg-Zn-Y alloy system [17].

A tensile test was performed on these cast alloys at room temperature with a strain-rate of $6.5 \times 10^{-4} \mathrm{~S}^{-1}$. Figure 4 shows the tensile properties of $\mathrm{Mg}_{98} \mathrm{Zn}_{1} \mathrm{Y}_{1^{-}}, \mathrm{Mg}_{96} \mathrm{Zn}_{2} \mathrm{Y}_{2^{-}}$, and $\mathrm{Mg}_{94} \mathrm{Zn}_{3} \mathrm{Y}_{3^{-}}$cast alloys. The $\mathrm{Mg}_{98} \mathrm{Zn}_{1} \mathrm{Y}_{1^{-}}$, $\mathrm{Mg}_{96} \mathrm{Zn}_{2} \mathrm{Y}_{2^{-}}$, and $\mathrm{Mg}_{94} \mathrm{Zn}_{3} \mathrm{Y}_{3^{-}}$cast alloys exhibited average $\sigma_{\mathrm{y}}$ values of 102 , 
130 , and $177 \mathrm{MPa}$, and average $\delta$ values of 16,11 , and $10 \%$, respectively. $\sigma_{\mathrm{y}}$ tends to increase with increasing $\mathrm{Zn}$ and $\mathrm{Y}$ contents, while $\delta$ decreases. The ductility of these cast alloys is influenced by the ductility of the LPSO phase because the LPSO phase forms at the grain boundary as observed in Fig. 2. In previous studies, we reported that the LPSO single phase exhibited compression strain of about $30 \%$ at room temperature and showed good cold-rolling properties compared to Pure- $\mathrm{Mg}$ at room temperature [22, 23]. These results suggest that the LPSO phase has deformability at room temperature, which indicates the ductility of the LPSO phase at room temperature.

The $\sigma_{\mathrm{y}}$ value of $\mathrm{Mg}_{94} \mathrm{Zn}_{3} \mathrm{Y}_{3}$ cast alloy is higher than that of typical a $\mathrm{Mg}$ cast alloy $\left(\mathrm{AZ} 91 \mathrm{D} ; \sigma_{\mathrm{y}}=150 \mathrm{MPa}\right)$. Moreover, elongations of $5 \%$ or greater are achieved in the Mg-Zn-Y cast states, suggesting that the LPSO- and $\mathrm{Mg}_{3} \mathrm{Zn}_{3} \mathrm{Y}_{2^{-}}$phases are appropriate strengthening phases in the $\mathrm{Mg}-\mathrm{Zn}-\mathrm{Y}$ alloy system.

Therefore, $\mathrm{Mg}$ alloy sheets were prepared using the $\mathrm{Mg}_{98} \mathrm{Zn}_{1} \mathrm{Y}_{1^{-}}$, $\mathrm{Mg}_{96} \mathrm{Zn}_{2} \mathrm{Y}_{2^{-}}$, and $\mathrm{Mg}_{94} \mathrm{Zn}_{3} \mathrm{Y}_{3^{-}}$cast alloys by hot-rolling. 


\subsection{Microstructure and mechanical properties of $\mathrm{Mg}-\mathrm{Zn}-\mathrm{Y}$ alloy sheets}

and their annealed states.

Figure 5 shows BEI images of cross section of (a) $\mathrm{Mg}_{98} \mathrm{Zn}_{1} \mathrm{Y}_{1}$ alloy sheet, (b) $\mathrm{Mg}_{96} \mathrm{Zn}_{2} \mathrm{Y}_{2}$ alloy sheet, and (c) $\mathrm{Mg}_{94} \mathrm{Zn}_{3} \mathrm{Y}_{3}$ alloy sheet, respectively. The LPSO- and Mg- phases are elongated along the rolling-direction (RD), shown in Figs. 5 (a), (b), and (c). On the other hand, the $\mathrm{Mg}_{3} \mathrm{Zn}_{3} \mathrm{Y}_{2}$ phase is refined by approximately $1 \mu \mathrm{m}$ and dispersed in the LPSO and Mg-phases by hot-rolling, as indicated by the white circles in Figs. 5 (a), (b), and (c). The basal planes of the LPSO phase and Mg phases are rotated toward the sheet plane by rolling [18]. The $\mathrm{Mg}_{3} \mathrm{Zn}_{3} \mathrm{Y}_{2}$ phase is located at the grain boundaries discontinuously with the LPSO phase in the as cast state. Therefore, refinement of the $\mathrm{Mg}_{3} \mathrm{Zn}_{3} \mathrm{Y}_{2}$ phase by hot-rolling plays an important role in refining the LPSO phase. The LPSO phase in the $\mathrm{Mg}_{98} \mathrm{Zn}_{1} \mathrm{Y}_{1^{-}}$and $\mathrm{Mg}_{96} \mathrm{Zn}_{2} \mathrm{Y}_{2^{-}}$alloy sheets was slightly refined by annealing, while the prolonged LPSO phase was fairly well retained. Therefore, there are no significant differences between the states before- and after annealing. Figure 6 shows (0002) pole figures of (a) $\mathrm{Mg}_{98} \mathrm{Zn}_{1} \mathrm{Y}_{1}$ alloy sheet, (b) $\mathrm{Mg}_{96} \mathrm{Zn}_{2} \mathrm{Y}_{2}$ alloy sheet, and (c) $\mathrm{Mg}_{94} \mathrm{Zn}_{3} \mathrm{Y}_{3}$ alloy sheet. The reflection angle (2 $\left.\theta\right)$ of the 
basal plane (00018) of the LPSO phase is 34 degrees, which is identical to that of pure-Mg. Therefore, the pole figure indicates reflections of the basal planes of both the LPSO- and Mg- phases. The maximum peak intensity of these alloy sheets is greater than 4.3 , which indicates that the basal plane textures of the LPSO- and Mg- phases are formed by hot-rolling. Considering the strong deformation anisotropy of the LPSO phase, as shown in Fig. 5, these XRD results correspond to the microstructure observation. However, the maximum peaks in the transverse direction (TD) are tilted approximately 10 degrees away from the nominal direction (ND). After hot-rolling, the TEM images indicate deformation kinks are frequently observed in the LPSO phase [18]. Deformation kinks are observed in inorganic materials, such as hexagonal metals, oxides, and carbides, with a c/a ratio greater than 1.73 [19]. Formation of the basal texture of the LPSO phase is more complicated than that the $\mathrm{Mg}$ phase because deformation kinks are formed by arbitrary angle rotations of the basal plane $[18,20]$. Therefore, after a $90 \%$ thickness reduction, double peaks can be observed in the basal pole figure, as shown in Fig. 6. Consequently, the LPSO- and Mg- phases are oriented such that their basal planes are close to the sheet plane. Figure 7 shows (0002) pole figures 
of (a) $\mathrm{Mg}_{98} \mathrm{Zn}_{1} \mathrm{Y}_{1}$ annealed sheet, (b) $\mathrm{Mg}_{96} \mathrm{Zn}_{2} \mathrm{Y}_{2}$ annealed sheet, and (c) $\mathrm{Mg}_{94} \mathrm{Zn}_{3} \mathrm{Y}_{3}$ annealed sheet, respectively. Although the maximum peak intensities of (a) $\mathrm{Mg}_{98} \mathrm{Zn}_{1} \mathrm{Y}_{1^{-}}$and (b) $\mathrm{Mg}_{96} \mathrm{Zn}_{2} \mathrm{Y}_{2^{-}}$annealed sheets decreases to 1.0 and 3.4 , respectively, the basal textures are appropriately retained. The SEM images suggest that the elongated LPSO phases are retained after annealing. Therefore, it is considered that the basal textures of the Mg phases decrease owing to re-crystallization. The maximum peak intensity of 8.5 represented by the $\mathrm{Mg}_{94} \mathrm{Zn}_{3} \mathrm{Y}_{3}$ annealed sheet is slightly lower than that of the as-rolled sheet. This result indicates that the strong basal texture of the LPSO phase is retained even after annealing. The area fraction of the LPSO phase of the $\mathrm{Mg}_{94} \mathrm{Zn}_{3} \mathrm{Y}_{3}$ alloy is the largest in the $\mathrm{Mg}-\mathrm{Zn}-\mathrm{Y}$ alloy system prepared in this study. The slip system of the LPSO phase increases above $673 \mathrm{~K}$, which is higher than that of the $\mathrm{Mg}$ phase [21]. Thus, re-crystallization of the LPSO phase is harder than the $\mathrm{Mg}$ phase by annealing. These results indicate that the microstructure of the $\mathrm{Mg}$ phase changes in Mg-Zn-Y alloy annealed sheets.

Figure 8 shows an inverse pole figure (IPF) image acquired by EBSD analysis of the $\mathrm{Mg}$ phase area in the sheet plane of the $\mathrm{Mg}_{98} \mathrm{Zn}_{1} \mathrm{Y}_{1}$ annealed 
sheet. Figure 8 also shows calculated (0001), (10-10), and (2-1-10) pole figures in the IPF image. The dark areas indicated by arrows in the IPF image correspond to the LPSO- or the $\mathrm{Mg}_{3} \mathrm{Zn}_{3} \mathrm{Y}_{2^{-}}$phases that are un-identified areas. Mg grains with 3 to $40 \mu \mathrm{m}$ are recognized in the IPF image. The peak in the (0001) pole figure divides between ND and TD, and spreads between the TD and RD. Furthermore, the peaks in the (10-10) and (2-1-10) pole figures are also spread between the RD and the ND. These results suggest that the strong basal plane texture of the $\mathrm{Mg}$ phase is reduced by randomization caused by re-crystallization. These re-crystallized $\mathrm{Mg}$ grains are also observed in the $\mathrm{Mg}_{96} \mathrm{Zn}_{2} \mathrm{Y}_{2}$ annealed sheet [16]. Thus, the $\mathrm{Mg}-\mathrm{Zn}-\mathrm{Y}$ annealed sheet, which has a randomized Mg phase and an LPSO phase with basal texture, could be prepared by hot-rolling and subsequent simple annealing.

A tensile test was performed at room temperature along the RD for the $\mathrm{Mg}-\mathrm{Zn}-\mathrm{Y}$ alloy sheets and their annealed states (at $773 \mathrm{~K}$ for $0.6 \mathrm{ks}$ ). The obtained tensile properties are summarized in Figure 9. These alloy sheets exhibited average $\sigma_{\mathrm{y}}$ values of 261,317 , and $380 \mathrm{MPa}$, and average $\delta$ values of 12,10 , and $6 \%$, respectively. A yield strength grater than $300 \mathrm{MPa}$ was 
achieved for the Mg-Zn-Y alloy sheet with $\mathrm{Zn}$ and $\mathrm{Y}$ contents of more than 2 at.\%. It was noticed that the specific strength $\left(\rho / \sigma_{y}\right)$ of $\operatorname{Mg}_{94} Z_{3} Y_{3}$ alloy sheet is $230 \mathrm{MPa} / \mathrm{Mg} \cdot \mathrm{m}^{-3}$, which is considerably higher than that of A7075-T6 $\left(180 \mathrm{MPa} / \mathrm{Mg} \cdot \mathrm{m}^{-3}\right)$. The $\sigma_{\mathrm{y}}$ values of these alloy sheets increase drastically after hot-rolling when compared to their cast state. As mentioned above, the LPSO phase forms a strong basal texture by hot-rolling. The basal planes of the LPSO phase in the alloy sheet are oriented parallel to the sheet plane, i.e., (00018) LPSO $\perp$ ND. Therefore, when a tensile test is performed along the direction parallel to $\mathrm{RD}$, Schmid factor for the basal slip of the LPSO phase is negligible. Consequently, the basal texture of the LPSO phase contributes to the strengthening of the alloy sheet owing to an increase in deformation resistance of the LPSO phase. A deformed LPSO phase, which is wavy along the RD, is observed in the SEM images of Fig. 5. This deformation morphology originates from kink deformation of the LPSO phase [18]. The above mentioned kink deformation creates many boundaries because deformation kinks are formed by rotation of the basal plane at arbitrary angles. In other words, kink deformation causes refinement of the LPSO phase. Therefore, the LPSO phase in the alloy sheet is strengthened by grain 
refinement resulting from kink deformation. Furthermore, as seen in Fig. 5, the $\mathrm{Mg}_{3} \mathrm{Zn}_{3} \mathrm{Y}_{2}$ phases of approximately $1 \mu \mathrm{m}$ are dispersed in the LPSO- and Mg- phases. Microstructure observations suggest that the strength of these alloy sheets resulted from mainly two factors: (i) the formation of the basal texture (where the basal plane is perpendicular to the ND) of the LPSO phase and (ii) the uniform dispersion of a fine $\mathrm{Mg}_{3} \mathrm{Zn}_{3} \mathrm{Y}_{2}$ phase.

The $\mathrm{Mg}_{98} \mathrm{Zn}_{1} \mathrm{Y}_{1^{-}}, \mathrm{Mg}_{96} \mathrm{Zn}_{2} \mathrm{Y}_{2^{-}}$, and $\mathrm{Mg}_{94} \mathrm{Zn}_{3} \mathrm{Y}_{3^{-}}$annealed sheets exhibited average $\sigma_{\mathrm{y}}$ values of 190,217 , and $293 \mathrm{MPa}$, and average $\delta$ values of 25,22 , and $15 \%$, respectively. After annealing, the elongation tended to increase, while the yield strength decreased. Large elongations of $20 \%$ or more were achieved in the $\operatorname{Mg}_{98} \mathrm{Zn}_{1} \mathrm{Y}_{1^{-}}$and $\mathrm{Mg}_{96} \mathrm{Zn}_{2} \mathrm{Y}_{2^{-}}$annealed sheets. Such large elongations presumably originate from randomization of the $\mathrm{Mg}$ phase by re-crystallization. On the other hand, the yield strength decreases owing to annealing. The yield strength of the annealed sheets is higher than $190 \mathrm{MPa}$ and greater, which is higher than that of the AZ31-O sheet $\left(\sigma_{\mathrm{y}}=170\right.$ $\mathrm{MPa}$ and $\delta=15 \%$ ). These results indicate that $\mathrm{Mg}$ alloy sheets of strength higher than $300 \mathrm{MPa}$ or elongations grater than $20 \%$ can be prepared by controlling the alloy compositions and their microstructure in the $\mathrm{Mg}-\mathrm{Zn}-\mathrm{Y}$ 
alloy system.

\subsection{Cold workability of $\mathrm{Mg}-\mathrm{Zn}-\mathrm{Y}$ alloy sheets and their annealed states evaluated by V-bending tests at room temperature}

To evaluate cold formability, a 90 degree V-bending test was performed at room temperature on the $\mathrm{Mg}-\mathrm{Zn}-\mathrm{Y}$ alloy sheets and their annealed states. For comparison, the V-bending test was also performed on the AZ31-O sheet. Figure 10 shows the appearance of the $\mathrm{Mg}_{98} \mathrm{Zn}_{1} \mathrm{Y}_{1^{-}}$and $\mathrm{Mg}_{96} \mathrm{Zn}_{2} \mathrm{Y}_{2^{-}}$alloy sheets, $\mathrm{Mg}_{98} \mathrm{Zn}_{1} \mathrm{Y}_{1^{-}}$and $\mathrm{Mg}_{96} \mathrm{Zn}_{2} \mathrm{Y}_{2^{-}}$annealed sheets, and the AZ31-O sheet after the V-bending tests with $R / t$ values of 3.8, 3.3, and 2.2, respectively. To simplify the determination of crack initiation, black paint was applied to the sheet surfaces. While cracks are not observed on the sheet surfaces with $R / t=3.8$, as indicated by white circles in Fig. 10, cracks were observed on the sheet surfaces with $R / t=2.2$. On the other hand, in the V-bending tests with $R / t=3.3$, a only the AZ31-O sheet shows cracks, indicating that the Mg-Zn-Y annealed sheets offer good cold workability. However, there may be visually unobservable cracks in the $\mathrm{Mg}-\mathrm{Zn}-\mathrm{Y}$ annealed sheets. To check for micro-cracks, SEM observations were 
performed at the tip of the bent area in the sheet after V-bending test. Figure 11 shows SEM images of cross-sections of the bent Mg-Zn-Y annealed sheets and bent AZ31-O sheet. After the $\mathrm{V}$-bending test with $R / t=2.2$, were observed in the Mg-Zn-Y annealed sheets and AZ31-O sheet. Cracks were observed in the SEM image of the AZ31-O sheet, while there were no cracks in the $\mathrm{Mg}_{98} \mathrm{Zn}_{1} \mathrm{Y}_{1^{-}}$and $\mathrm{Mg}_{96} \mathrm{Zn}_{2} \mathrm{Y}_{2^{-}}$annealed sheets after the V-bending tests with $R / t=3.3$.

Table 2 shows the V-bending limit for the $\mathrm{Mg}-\mathrm{Zn}-\mathrm{Y}$ alloy sheet, Mg-Zn-Y annealed sheet, and $\mathrm{AZ31-O}$ sheet. While the $\mathrm{Mg}_{94} \mathrm{Zn}_{3} \mathrm{Y}_{3}$ alloy sheet could not bend for $R / t=5.0$, the other sheets could be bent for $R / t$ less than 5.0. The $\delta$ of the $\operatorname{Mg}_{94} \mathrm{Zn}_{3} \mathrm{Y}_{3}$ alloy sheet was $8 \%$, which is the lowest for alloy sheets used in this study. However, after annealing, the $\operatorname{Mg}_{94} \mathrm{Zn}_{3} \mathrm{Y}_{3}$ alloy sheet could be bent with $R / t=5.0$. The $\mathrm{Mg}_{96} \mathrm{Zn}_{2} \mathrm{Y}_{2}$ alloy sheet, which exhibited a yield strength of higher than $300 \mathrm{MPa}$, could also be bent. On the other hand, the $\mathrm{Mg}_{98} \mathrm{Zn}_{1} \mathrm{Y}_{1^{-}}$and $\mathrm{Mg}_{96} \mathrm{Zn}_{2} \mathrm{Y}_{2^{-}}$alloy annealed sheets could be bent with $R / t=3.3$, which is less than that for the AZ 31-O sheet. This result shows that the $\mathrm{Mg}_{98} \mathrm{Zn}_{1} \mathrm{Y}_{1^{-}}$and $\mathrm{Mg}_{96} \mathrm{Zn}_{2} \mathrm{Y}_{2^{-}}$annealed sheets offer better cold workability than the AZ 31-O sheet. The AZ31-O sheet exhibited $\sigma_{\mathrm{y}}$ value of 
$170 \mathrm{MPa}$, which is lower than that of the $\mathrm{Mg}-\mathrm{Zn}-\mathrm{Y}$ alloy sheets and the Mg-Zn-Y annealed sheet. Kohzu et al. succeeded in the development of texture randomized $\mathrm{Mg}$ sheets by annealing (773K) and subsequent isothermal-rolling (298 - 573K) by using AZ 31 sheets. For a randomized AZ31 sheet with Mg grains of approximately $30 \mu \mathrm{m}, R / t=1.4$ was achieved for V-bending at room temperature [24]. This result indicates that the texture randomization significantly improve the cold workability. From the IPF image in Fig. 8, it is reasonable to conclude that the texture randomization of the $\mathrm{Mg}$ phase enhances cold workability, even though the fiber texture of the LPSO phase inhibits the ductility to a certain extent. Therefore, the $\mathrm{Mg}_{98} \mathrm{Zn}_{1} \mathrm{Y}_{1^{-}}$and $\mathrm{Mg}_{96} \mathrm{Zn}_{2} \mathrm{Y}_{2}$-annealed sheets offer better cold workability and higher strength than the AZ31-O sheet.

From the above-mentioned results, it is concluded that $\mathrm{Mg}$ alloy sheets of yield strength higher than $300 \mathrm{MPa}$ or good cold workability can be prepared by controlling the alloy compositions and their microstructure in the Mg-Zn-Y alloy system.

\section{Conclusions}


$\mathrm{Mg}_{98} \mathrm{Zn}_{1} \mathrm{Y}_{1^{-}}, \mathrm{Mg}_{96} \mathrm{Zn}_{2} \mathrm{Y}_{2^{-}}$, and $\mathrm{Mg}_{94} \mathrm{Zn}_{3} \mathrm{Y}_{3^{-}}$alloy sheets were prepared by hot-rolling, using Mg-Zn-Y cast alloys. The microstructure and mechanical properties of the alloy sheets and their annealed states were investigated. Furthermore, the cold workability was evaluated by $\mathrm{V}$ bending tests, and compared with the commercial AZ31-O sheet. The results can be summarized as follows:

1. The $\mathrm{Mg}_{98} \mathrm{Zn}_{1} \mathrm{Y}_{1^{-}}, \mathrm{Mg}_{96} \mathrm{Zn}_{2} \mathrm{Y}_{2^{-}}$, and $\mathrm{Mg}_{94} \mathrm{Zn}_{3} \mathrm{Y}_{3^{-}}$cast alloys consisted of Mg-, 18R-type LPSO-, and $\mathrm{Mg}_{3} \mathrm{Zn}_{3} \mathrm{Y}_{2-}$ phases. Therefore, the $\mathrm{Mg}-\mathrm{Zn}-\mathrm{Y}$ cast alloys prepared in this study consisted of three phases.

2. The $\mathrm{Mg}_{98} \mathrm{Zn}_{1} \mathrm{Y}_{1^{-}}, \mathrm{Mg}_{96} \mathrm{Zn}_{2} \mathrm{Y}_{2^{-}}$, and $\mathrm{Mg}_{94} \mathrm{Zn}_{3} \mathrm{Y}_{3^{-}}$alloy sheets exhibited yield strengths of 261,317 , and $380 \mathrm{MPa}$, and elongations of 12,10 , and $6 \%$, respectively. The yield strength obtained for the $\mathrm{Mg}-\mathrm{Zn}-\mathrm{Y}$ alloy sheets with $\mathrm{Zn}$ and Y contents of more than 2 at.\%. was higher than 300 MPa.

3. The $\mathrm{Mg}_{98} \mathrm{Zn}_{1} \mathrm{Y}_{1^{-}}, \quad \mathrm{Mg}_{96} \mathrm{Zn}_{2} \mathrm{Y}_{2^{-}}$, and $\mathrm{Mg}_{94} \mathrm{Zn}_{3} \mathrm{Y}_{3^{-}}$annealed sheets exhibited yield strengths of 190, 217, and $293 \mathrm{MPa}$, and elongations of 
25,22 , and $15 \%$, respectively. After annealing, the elongations exhibited by the $\mathrm{Mg}_{98} \mathrm{Zn}_{1} \mathrm{Y}_{1^{-}}$and $\mathrm{Mg}_{96} \mathrm{Zn}_{2} \mathrm{Y}_{2^{-}}$alloy sheets were greater than $20 \%$.

4. Basal textures of the LPSO- and Mg- phases were formed in the $\mathrm{Mg}-\mathrm{Zn}-\mathrm{Y}$ alloy sheets. The basal texture of the $\mathrm{Mg}$ phase in the $\mathrm{Mg}_{98} \mathrm{Zn}_{1} \mathrm{Y}_{1}$ annealed sheet was reduced by randomization owing to re-crystallization.

5. The minimum bending radius per thickness of the $\operatorname{Mg}_{98} Z_{n_{1}} Y_{1^{-}}$and $\mathrm{Mg}_{96} \mathrm{Zn}_{2} \mathrm{Y}_{2^{-}}$annealed sheets was 3.3, which was lower than that of the Mg-Zn-Y alloy sheets or the AZ31-O sheet. The $\mathrm{Mg}_{98} \mathrm{Zn}_{1} \mathrm{Y}_{1^{-}}$and $\mathrm{Mg}_{96} \mathrm{Zn}_{2} \mathrm{Y}_{2^{-}}$annealed sheets offer better cold workability than the AZ 31-O sheet.

\section{Acknowldgements}

This study was supported by the Kumamoto Prefecture Collaboration of Regional Entities for the Advancement of Technological Excellence, JST. 


\section{References}

[1] Y. Kawamura, K. Hayashi, A. Inoue, T. Masumoto, Material Trans. JIM 42 (2001) 1172-1726.

[2] A. Inoue, Y. Kawamura, M. Matsusita, K. Hayashi, J. Koike, J. Mater. Res. Soc. 16 (2001) 1894-1900.

[3] E. Abe, Y. Kawamura, K. Hayashi, A. Inoue, Acta Materialia. 50 (2002) $3845-3857$.

[4] T. Itoi, T. Seimiya, Y. Kawamura, M. Hirohashi, Scripta Materialia. 51 (2004) 107-111.

[5] M. Nishida, Y. Kawamura, T. Yamamuro, Mater. Sci. Eng. A 375-377 (2004) 1217-1223.

[6] M. Matsuda, S. Ii, Y. Kawamura, Y. Ikuhara, M. Nishida, Mater. Sci. Eng. A 393 (2005) 269-274.

[7] D. H. Ping, K. Hono, Y. Kawamura, A. Inoue, Phil. Mag. Lett. 82 (2002) 543-546.

[8] H. Yokobayashi, K. Kishida, H. Inui, M. Yamasaki, Y. Kawamura, MRS Symp. Proc. 1295 (2011) 267-272.

[9] H. Yokobayashi, K. Kishida, H. Inui, M. Yamasaki, Y. Kawamura, Acta 
Materialia. 59 (2011) 7287-7299.

[10] D. Egusa, E. Abe , Acta Materialia. 60 (2012) 166-178.

[11] E. Abe, A. Ono, T. Itoi, M. Yamasaki, Y. Kawamura, Phil. Mag. Lett. 91 (2011) 690-696.

[12] Y. Kawamura, T. Kasahara, S. Izumi, M. Yamasaki, Scripta Materialia. 55 (2006) 453-456.

[13] S. Yoshimoto, M. Yamasaki, Y. Kawamura, Material Trans. JIM. 47 (2006) 959-967.

[14] M. Yamasaki, K. Hashimoto, K. Hagihara, Y. Kawamura, Acta Materialia. 59 (2011) 3646-3658.

[15] T. Itoi, K. Takahashi, H. Moriyama, M. Hirohashi, Scripta Materialia. 59 (2008) 1155-1158.

[16] T. Itoi, T. Inazawa, Y. Kuroda, M. Yamasaki, Y. Kawamura, Mat. Lett. 64 (2010) 2277-2280.

[17] Z. P. Luo, S. Q. Zhang. J. Mater. Sci. Lett. 19 (2000) 813-815.

[18] T. Itoi, T. Suzuki, Y. Kawamura, M. Hirohashi, Material Trans. 51 (2010) 1536-1542.

[19] J. B. Hess, C. S. Barrett, Trans. AIME. 185 (1494) 599. 
[20] K. Hagihara, N. Yokotani, U. Umakoshi, Intermetallics. 18 (2010) 267-276.

[21] K. Hagihara, A. Kinoshita, Y. Sugino, M. Yamasaki, Y. Kawawmura, H. Y. Yasuda, U. Umakoshi, Intermetallics. 18 (2010) 1079-1085.

[22] T. Itoi, T. Inazawa, M. Hirohashi, Trans. JSME. Part A. 76 (2010) 1769-1774.

[23] T. Itoi, R. Ichikawa, M, Hirohashi, Material Science Forum. 706-709 (2012) 1176-1180.

[24] M. Kohzu, K. Kii, Y. Nagata, H. Nishino, K. Higashi, H. Inoue, Material Trans. 51 (2010) 749-755. 


\section{Figures and captions}

Figure 1. Schematic of V-bending test with dimensions.

Figure 2. SEM backscatter electron images (BEIs) of (a) $\mathrm{Mg}_{98} \mathrm{Zn}_{1} \mathrm{Y}_{1}$ cast alloy, (b) $\mathrm{Mg}_{96} \mathrm{Zn}_{2} \mathrm{Y}_{2}$ cast alloy, and (c) $\mathrm{Mg}_{94} \mathrm{Zn}_{3} \mathrm{Y}_{3}$ cast alloy. White circles in these images indicate the $\mathrm{Mg}_{3} \mathrm{Zn}_{3} \mathrm{Y}_{2}$ phase.

Figure 3. (a) Electron Diffraction (ED) pattern, (b) High Resolution Transmission Electron Microscope (HRTEM) image, and (c) HAADF-STEM image of the LPSO phase.

Figure 4. Tensile property of the $\mathrm{Mg}_{98} \mathrm{Zn}_{1} \mathrm{Y}_{1^{-}}, \mathrm{Mg}_{96} \mathrm{Zn}_{2} \mathrm{Y}_{2^{-}}$, and $\mathrm{Mg}_{94} \mathrm{Zn}_{3} \mathrm{Y}_{3}-$ cast alloys at room temperature.

Figure 5. BEI images of cross-section of (a) $\mathrm{Mg}_{98} \mathrm{Zn}_{1} \mathrm{Y}_{1}$ alloy sheet, (b) $\mathrm{Mg}_{96} \mathrm{Zn}_{2} \mathrm{Y}_{2}$ alloy sheet, and (c) $\mathrm{Mg}_{94} \mathrm{Zn}_{3} \mathrm{Y}_{3}$ alloy sheet.

Figure 6. (0002) pole figures of (a) $\mathrm{Mg}_{98} \mathrm{Zn}_{1} \mathrm{Y}_{1}$ alloy sheet, (b) $\mathrm{Mg}_{96} \mathrm{Zn}_{2} \mathrm{Y}_{2}$ alloy sheet, and (c) $\mathrm{Mg}_{94} \mathrm{Zn}_{3} \mathrm{Y}_{3}$ alloy sheet. Double peaks are observed in pole figures indicated by allows.

Figure 7. (0002) pole figures of (a) $\mathrm{Mg}_{98} \mathrm{Zn}_{1} \mathrm{Y}_{1}$ alloy sheet, (b) $\mathrm{Mg}_{96} \mathrm{Zn}_{2} \mathrm{Y}_{2}$ alloy sheet, and (c) $\mathrm{Mg}_{94} \mathrm{Zn}_{3} \mathrm{Y}_{3}$ alloy sheet after annealing at $773 \mathrm{~K}$ for 0.6 ks. 
Figure 8. An inverse pole figure (IPF) image acquired by EBSD analysis taken from the $\mathrm{Mg}$ phase area in a plane of $\mathrm{Mg}_{98} \mathrm{Zn}_{1} \mathrm{Y}_{1}$ alloy sheet annealed at $773 \mathrm{~K}$ for $0.6 \mathrm{ks}$. Calculated (0001), (10-10) and (2-1-10) pole figures in the IPF image are also indicated.

Figure 9. Tensile property of the $\mathrm{Mg}_{98} \mathrm{Zn}_{1} \mathrm{Y}_{1^{-}}, \mathrm{Mg}_{96} \mathrm{Zn}_{2} \mathrm{Y}_{2^{-}}$, and $\mathrm{Mg}_{94} \mathrm{Zn}_{3} \mathrm{Y}_{3^{-}}$ alloy sheets and their annealed states $(773 \mathrm{~K}$ for $0.6 \mathrm{ks})$ at room temperature. Figure 10. Appearance of the $\mathrm{Mg}_{98} \mathrm{Zn}_{1} \mathrm{Y}_{1^{-}}, \mathrm{Mg}_{96} \mathrm{Zn}_{2} \mathrm{Y}_{2^{-}}$annealed sheets, and AZ31-O sheet after V-bending test with $R / t$ of $3.8,3.3$ and 2.2 , respectively. After the V-bending test, cracks in bent sheets were observed as indicated by white allows.

Figure 11. SEM images of bent $\mathrm{Mg}_{98} \mathrm{Zn}_{1} \mathrm{Y}_{1^{-}}, \mathrm{Mg}_{96} \mathrm{Zn}_{2} \mathrm{Y}_{2^{-}}$annealed sheets, and AZ31-O sheet with $R / t$ of 3.3 and 2.2 , respectively.

Table 1. Ratio $R / t$ in V-bending tests, where $R$ is the tip radius of punches and $t=0.8(\mathrm{~mm})$ is the sheet thickness.

Table 2. V-bending limit of Mg-Zn-Y alloy sheet, Mg-Zn-Y annealed sheet and AZ31-O sheet. After the V-bending test, cracks in bent sheets are recognized by visual inspection (Fig. 10) and using an SEM (Fig. 11). The (non)occurrence of a crack in a bent sheet is denoted by $(\circ) \times$. 


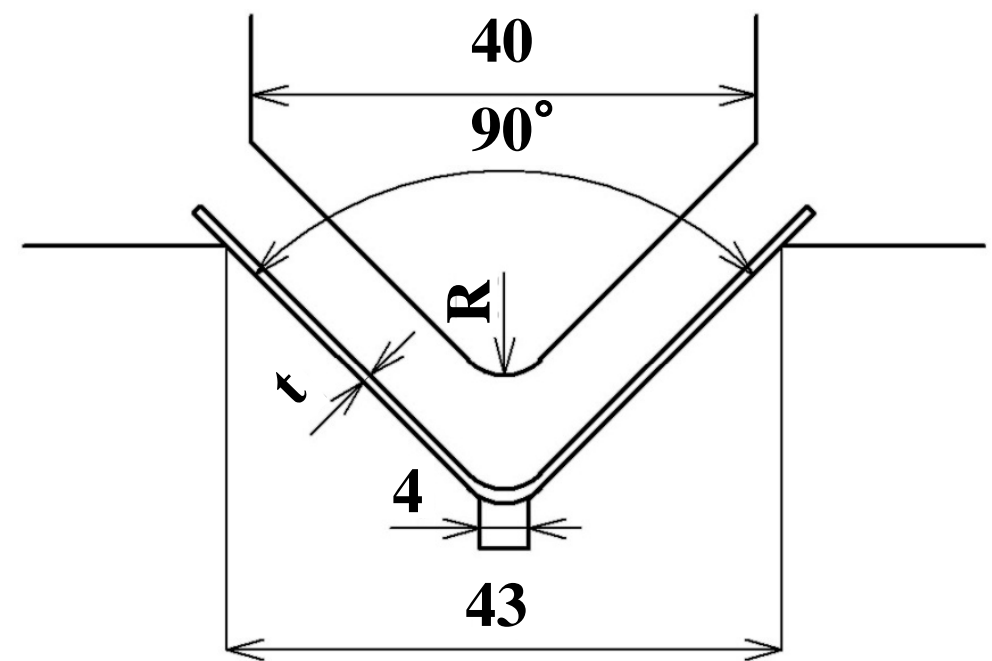

Figure 1. Schematic of V-bending test with dimensions. 


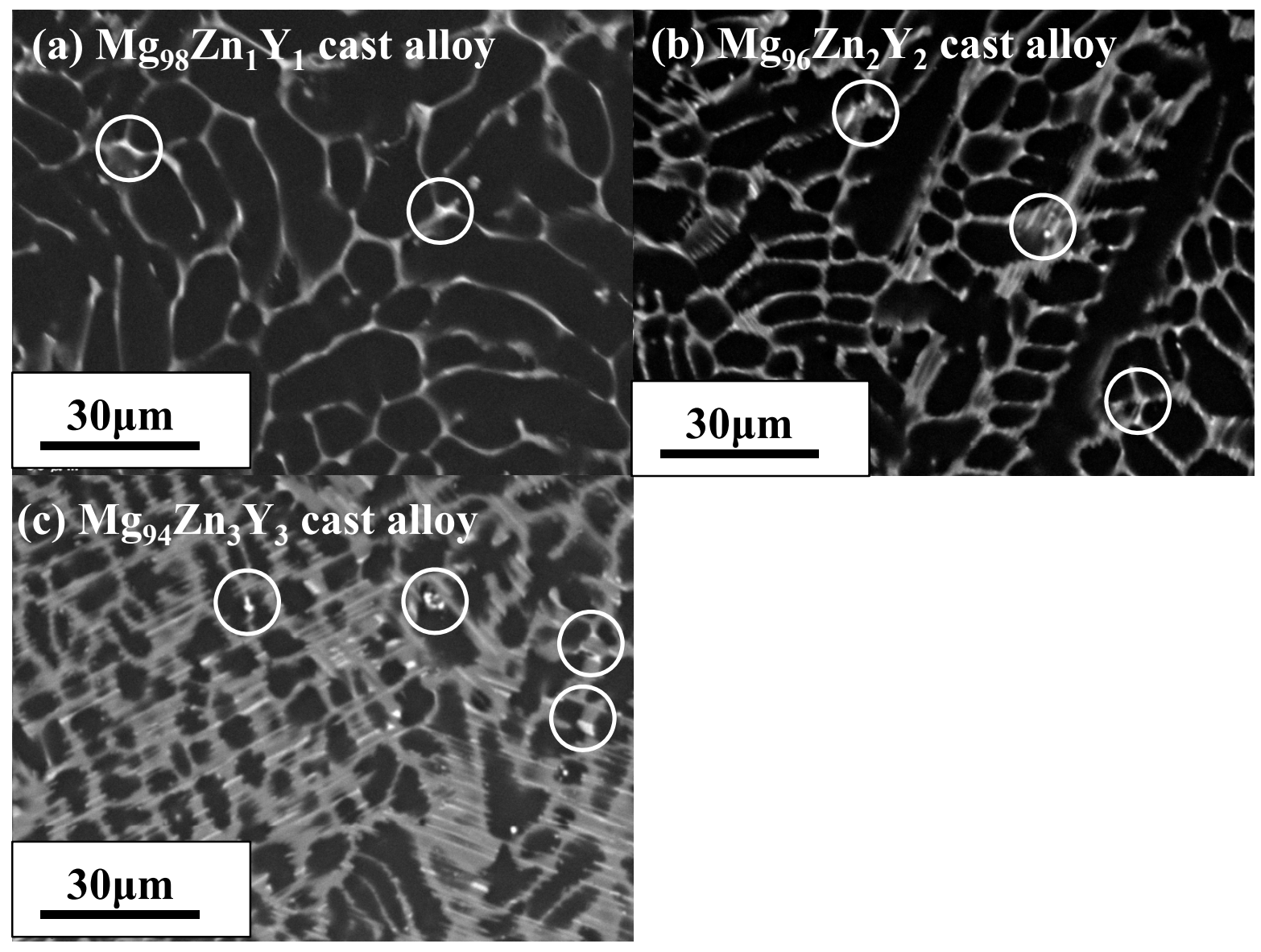

Figure 2. SEM backscatter electron images (BEIs) of (a) $\mathrm{Mg}_{98} \mathrm{Zn}_{1} \mathrm{Y}_{1}$ cast alloy, (b) $\mathrm{Mg}_{96} \mathrm{Zn}_{2} \mathrm{Y}_{2}$ cast alloy, and (c) $\mathrm{Mg}_{94} \mathrm{Zn}_{3} \mathrm{Y}_{3}$ cast alloy. White circles in these images indicate the $\mathrm{Mg}_{3} \mathrm{Zn}_{3} Y_{2}$ phase. 


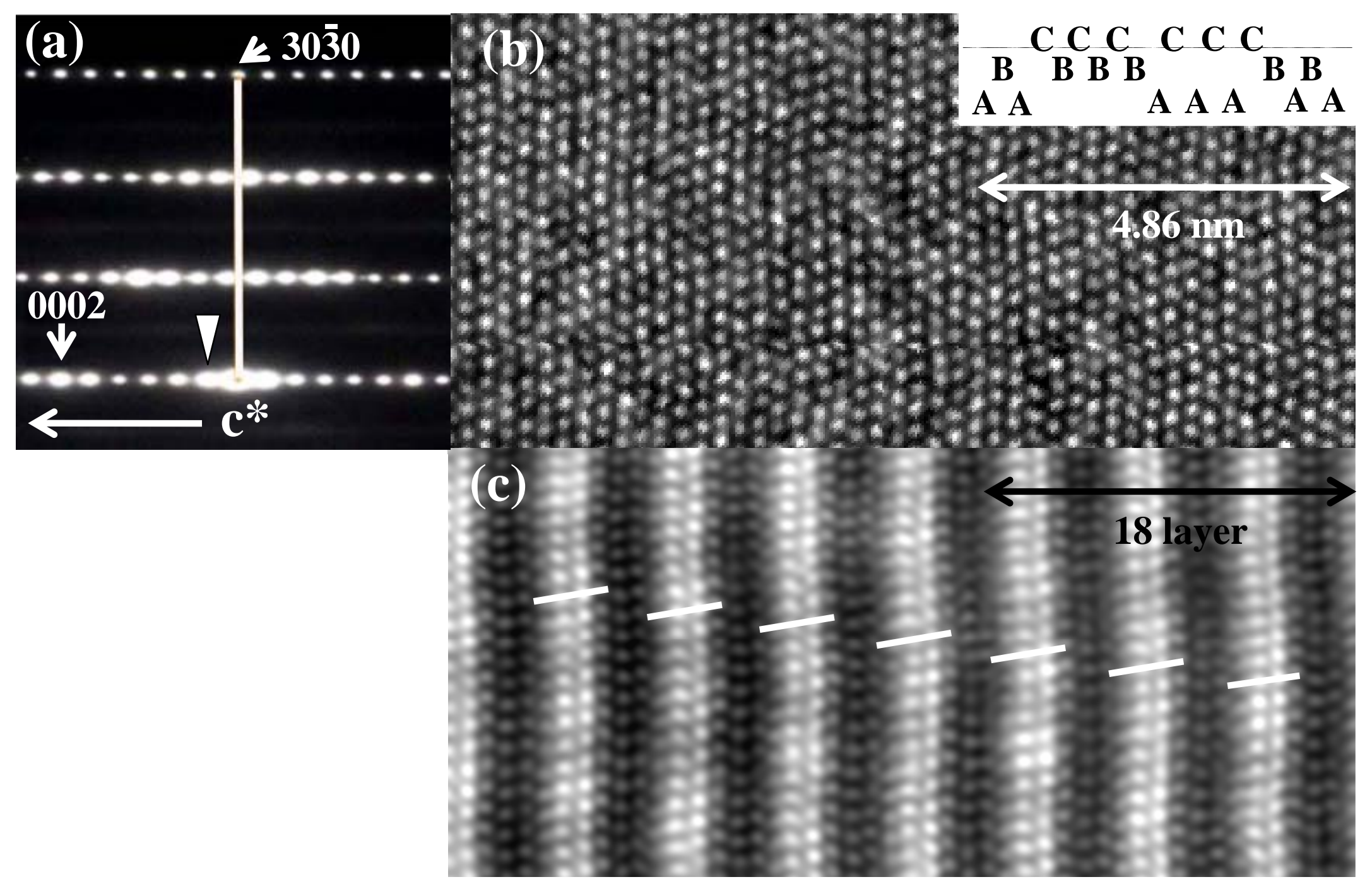

Figure 3. (a) Electron Diffraction (ED) pattern, (b) High Resolution Transmission Electron Microscope (HRTEM) image, and (c) HAADFSTEM image of the LPSO phase. 


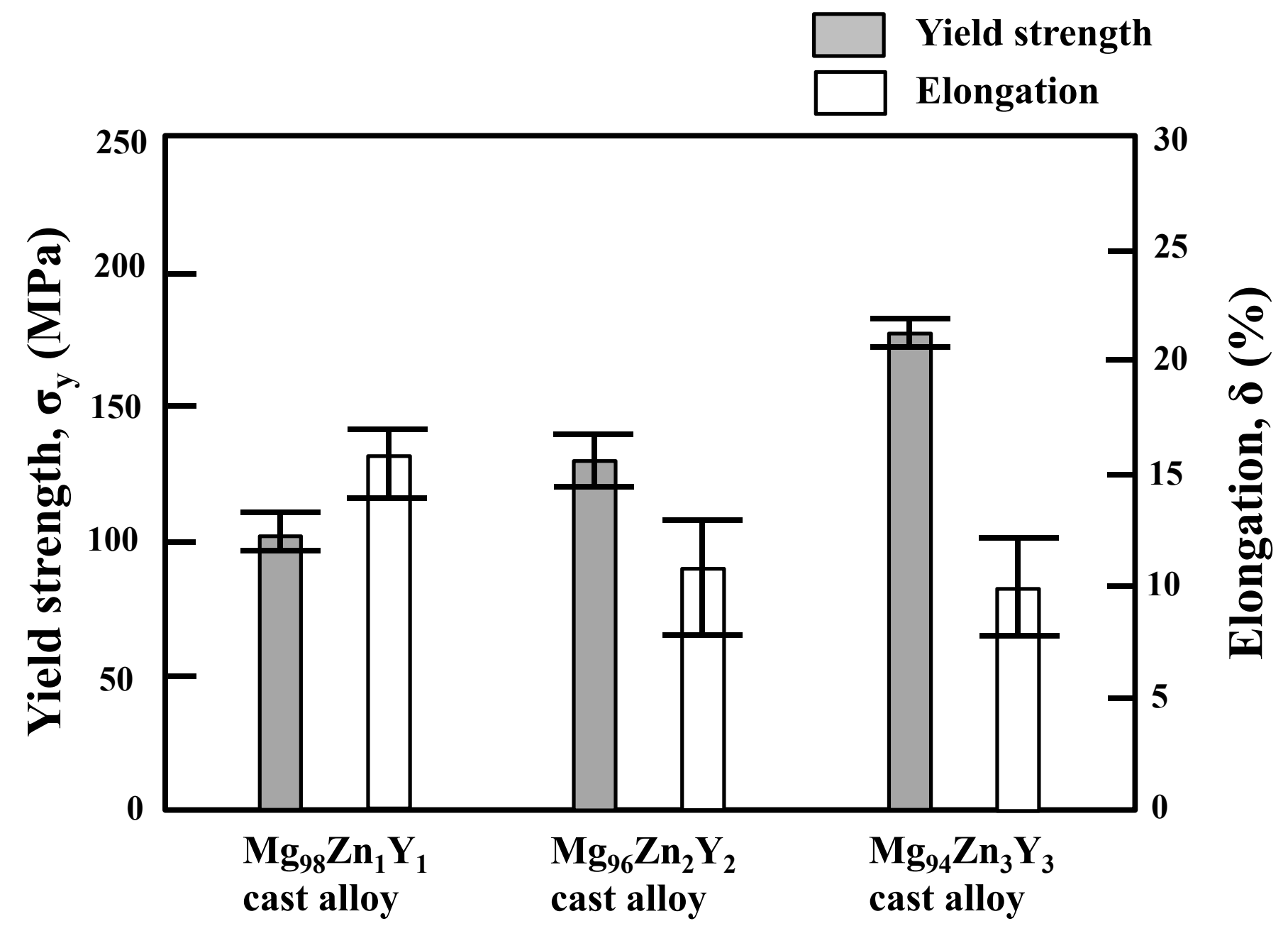

Figure 4. Tensile property of the $\mathrm{Mg}_{98} \mathrm{Zn}_{1} \mathrm{Y}_{1^{-}}, \mathrm{Mg}_{96} \mathrm{Zn}_{2} \mathrm{Y}_{2^{-}}$, and $\mathrm{Mg}_{94} \mathrm{Zn}_{3} \mathrm{Y}_{3}$ - cast alloys at room temperature. 


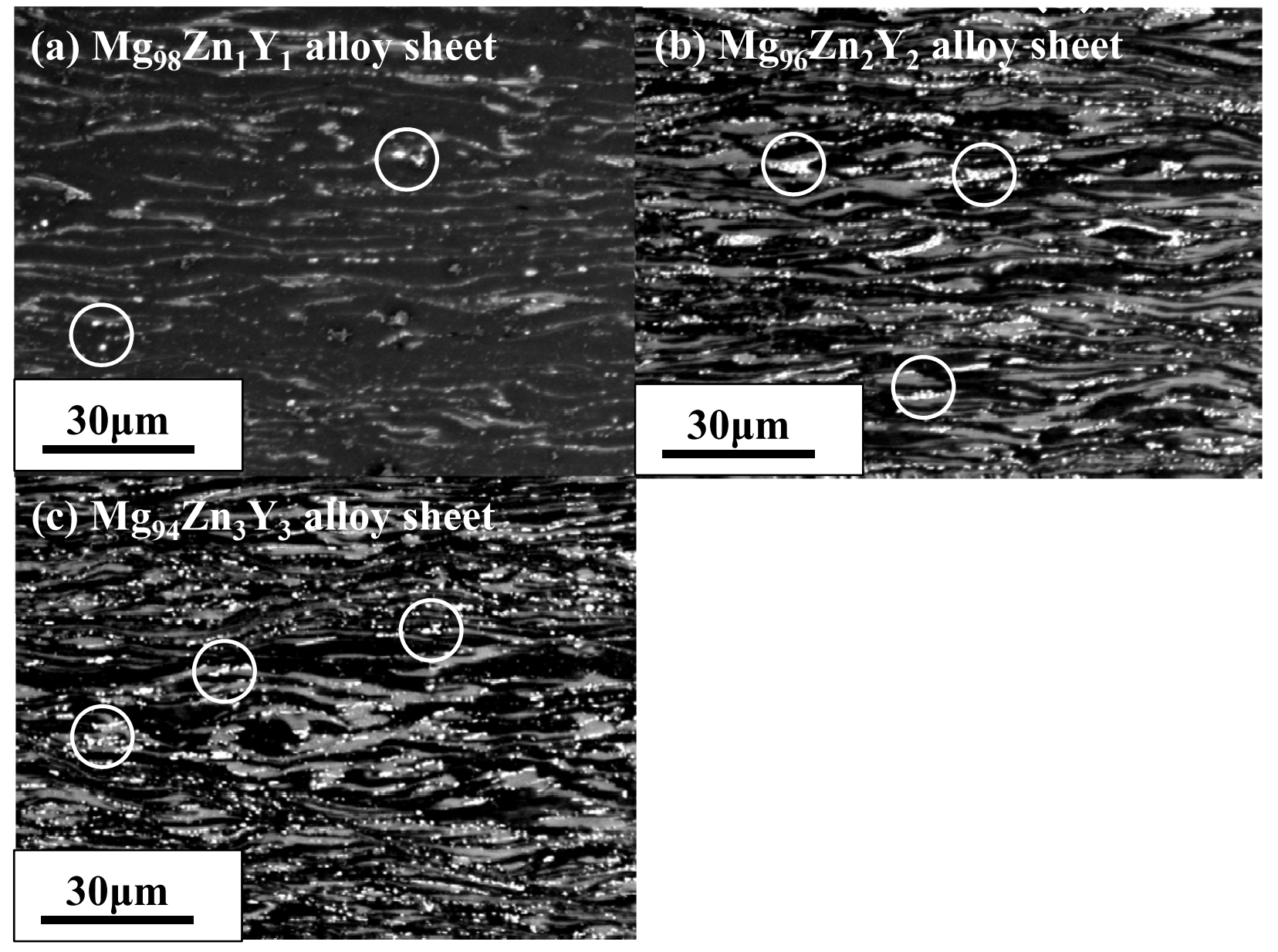

Figure 5. BEI images of cross section of (a) $\mathrm{Mg}_{98} \mathrm{Zn}_{1} \mathrm{Y}_{1}$ alloy sheet, (b) $\mathrm{Mg}_{96} \mathrm{Zn}_{2} \mathrm{Y}_{2}$ alloy sheet, and (c) $\mathrm{Mg}_{94} \mathrm{Zn}_{3} \mathrm{Y}_{3}$ alloy sheet. 
(a) $\mathrm{Mg}_{98} \mathrm{Zn}_{1} \mathrm{Y}_{1}$ alloy sheet

(b) $\operatorname{Mg}_{96} \mathrm{Zn}_{2} \mathbf{Y}_{2}$ alloy sheet
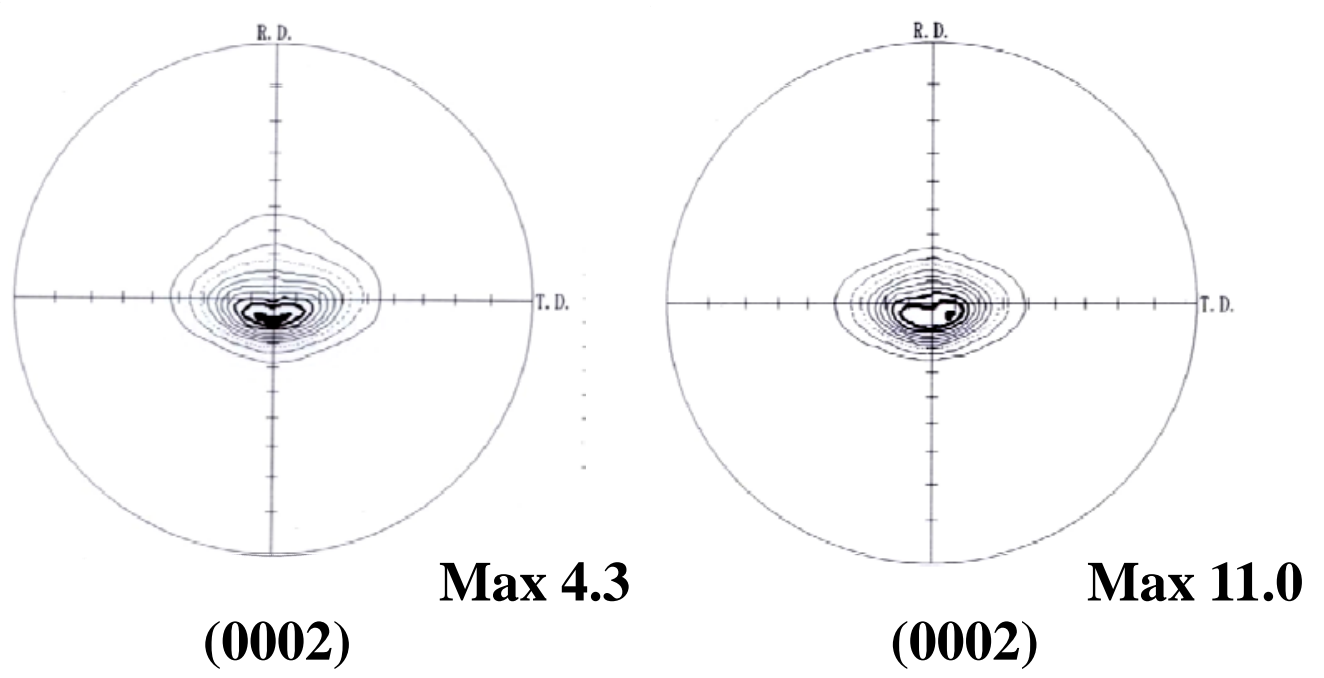

(c) $\mathrm{Mg}_{94} \mathrm{Zn}_{3} \mathbf{Y}_{3}$ alloy sheet

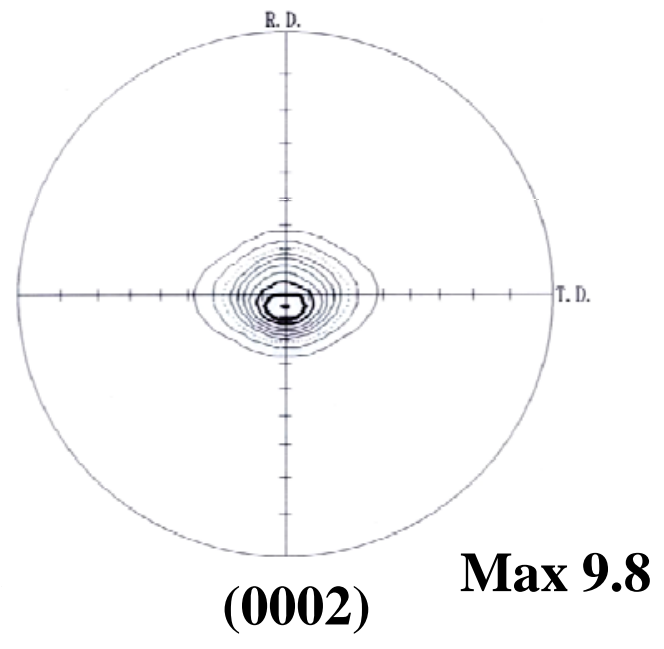

Figure 6. (0002) pole figures of (a) $\mathrm{Mg}_{98} \mathrm{Zn}_{1} \mathrm{Y}_{1}$ alloy sheet, (b) $\mathrm{Mg}_{96} \mathrm{Zn}_{2} \mathrm{Y}_{2}$ alloy sheet, and (c) $\mathrm{Mg}_{94} \mathrm{Zn}_{3} \mathrm{Y}_{3}$ alloy sheet. 
(a) $\mathrm{Mg}_{98} \mathrm{Zn}_{1} \mathrm{Y}_{1}$ alloy sheet annealed at $773 \mathrm{~K} 0.6 \mathrm{ks}$

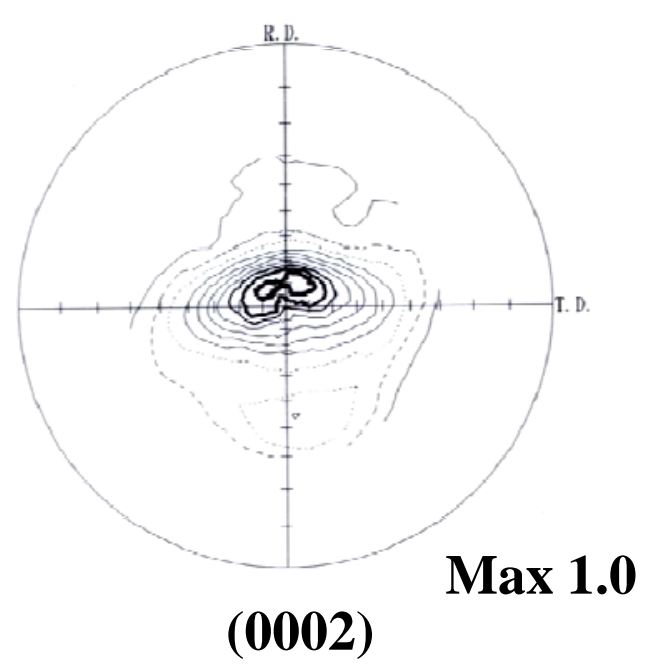

(c) $\mathrm{Mg}_{94} \mathrm{Zn}_{3} \mathbf{Y}_{3}$ alloy sheet annealed at $773 \mathrm{~K} 0.6 \mathrm{ks}$

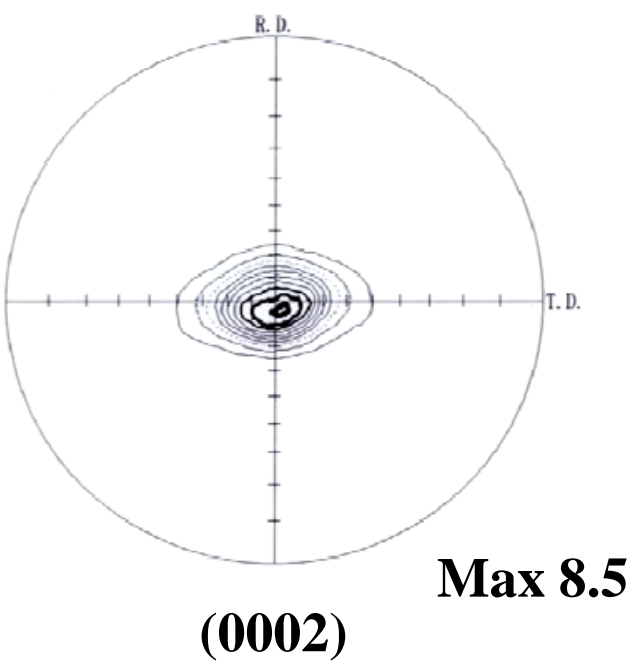

Figure 7. (0002) pole figures of (a) $\mathrm{Mg}_{98} \mathrm{Zn}_{1} \mathrm{Y}_{1}$ alloy sheet, (b) $\mathrm{Mg}_{96} \mathrm{Zn}_{2} \mathrm{Y}_{2}$ alloy sheet, and (c) $\mathrm{Mg}_{94} \mathrm{Zn}_{3} \mathrm{Y}_{3}$ alloy sheet after annealing at $773 \mathrm{~K}$ for $0.6 \mathrm{ks}$. (b) $\mathrm{Mg}_{96} \mathrm{Zn}_{2} \mathrm{Y}_{2}$ alloy sheet annealed at $773 \mathrm{~K} 0.6 \mathrm{ks}$

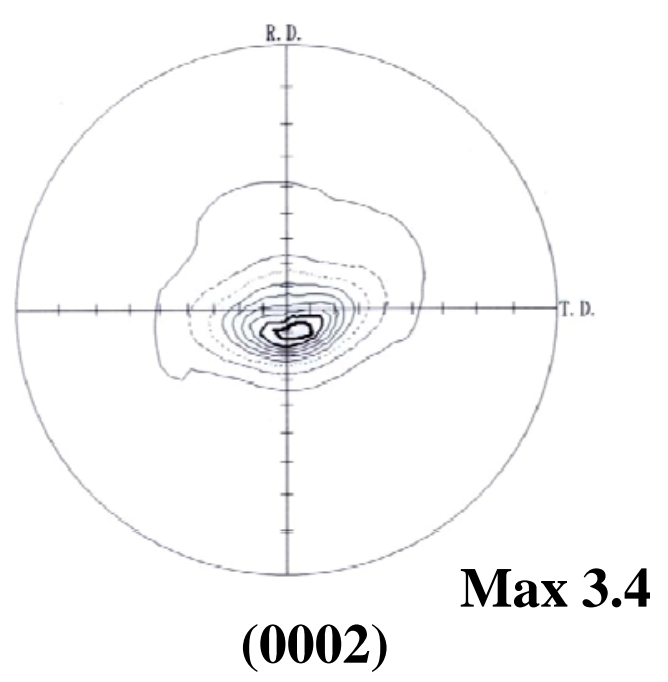

(0002) 

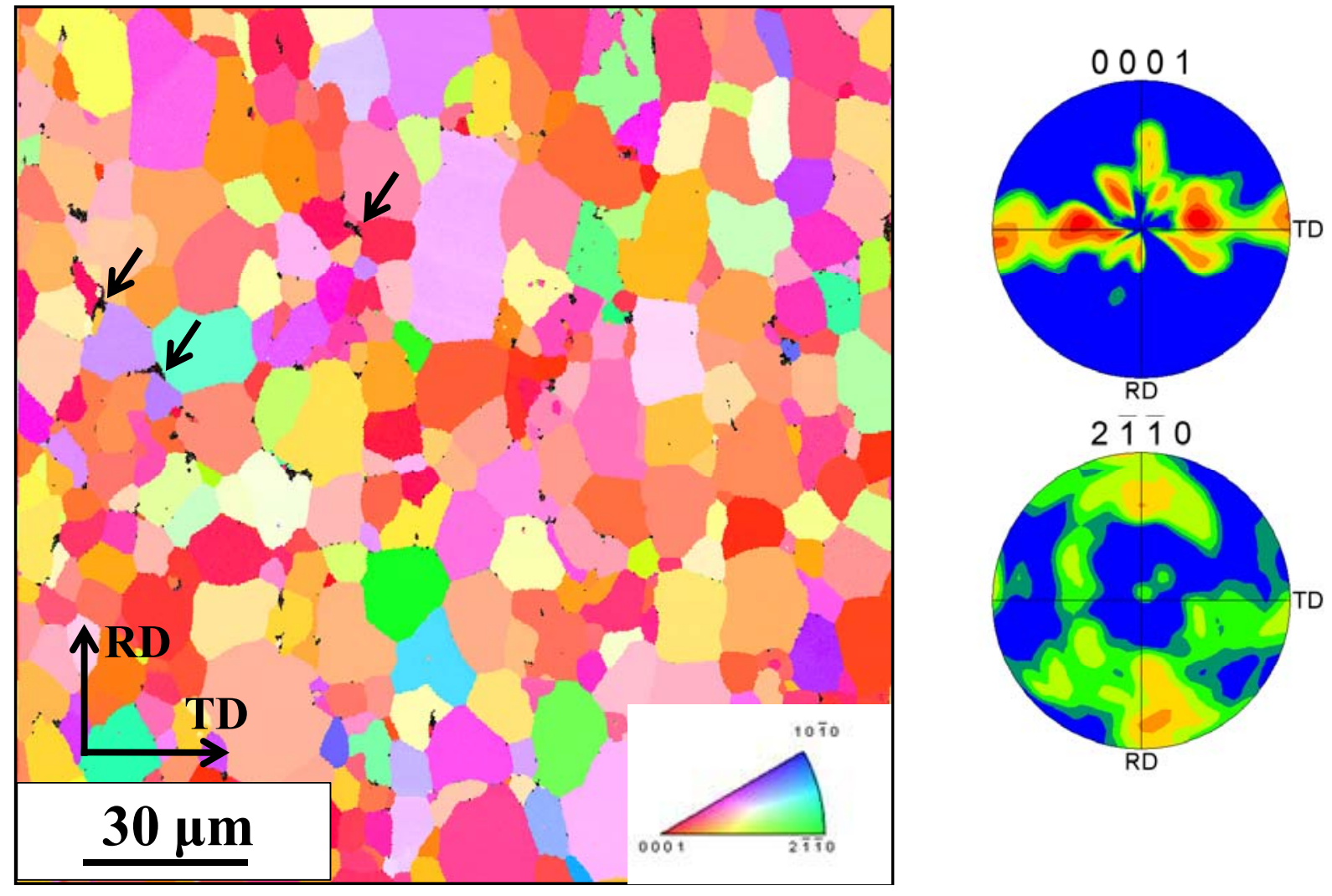

$2 \overline{1} \overline{1} 0$
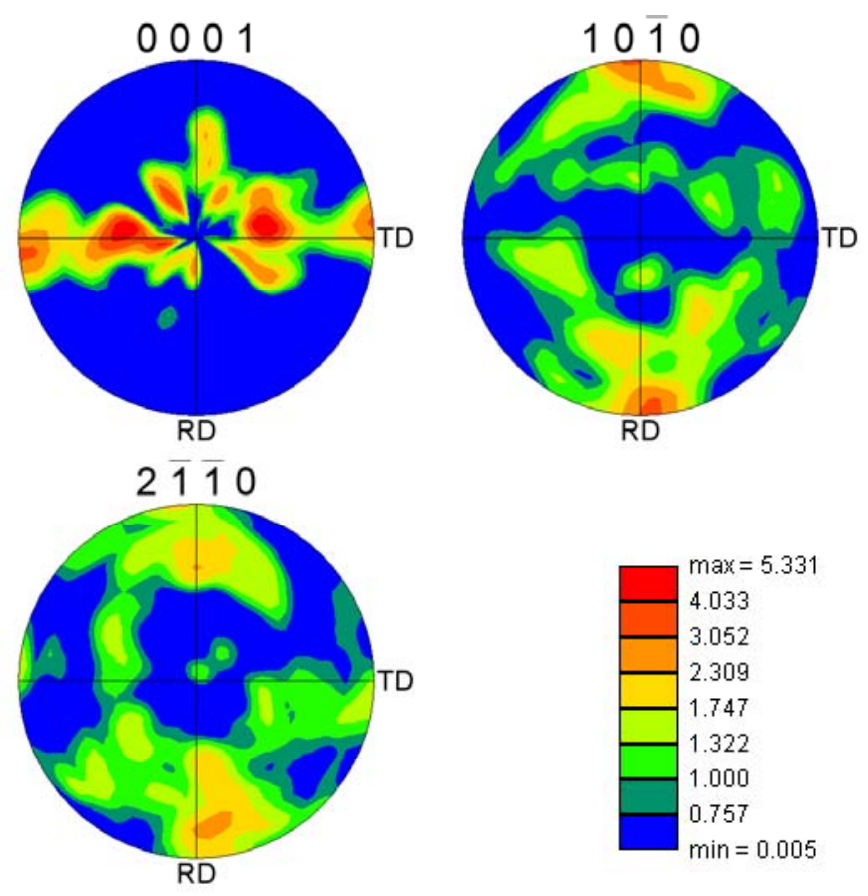

RD

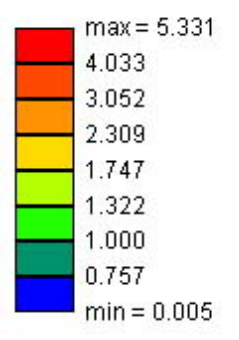

Figure 8. An inverse pole figure (IPF) image acquired by EBSD analysis taken from the $\mathrm{Mg}$ phase area in a plane of $\mathrm{Mg}_{98} \mathrm{Zn}_{1} \mathrm{Y}_{1}$ alloy sheet annealed at $773 \mathrm{~K}$ for $0.6 \mathrm{ks}$. Calculated (0001), (10-10) and (2-1-10) pole figures in the IPF image are also indicated. 


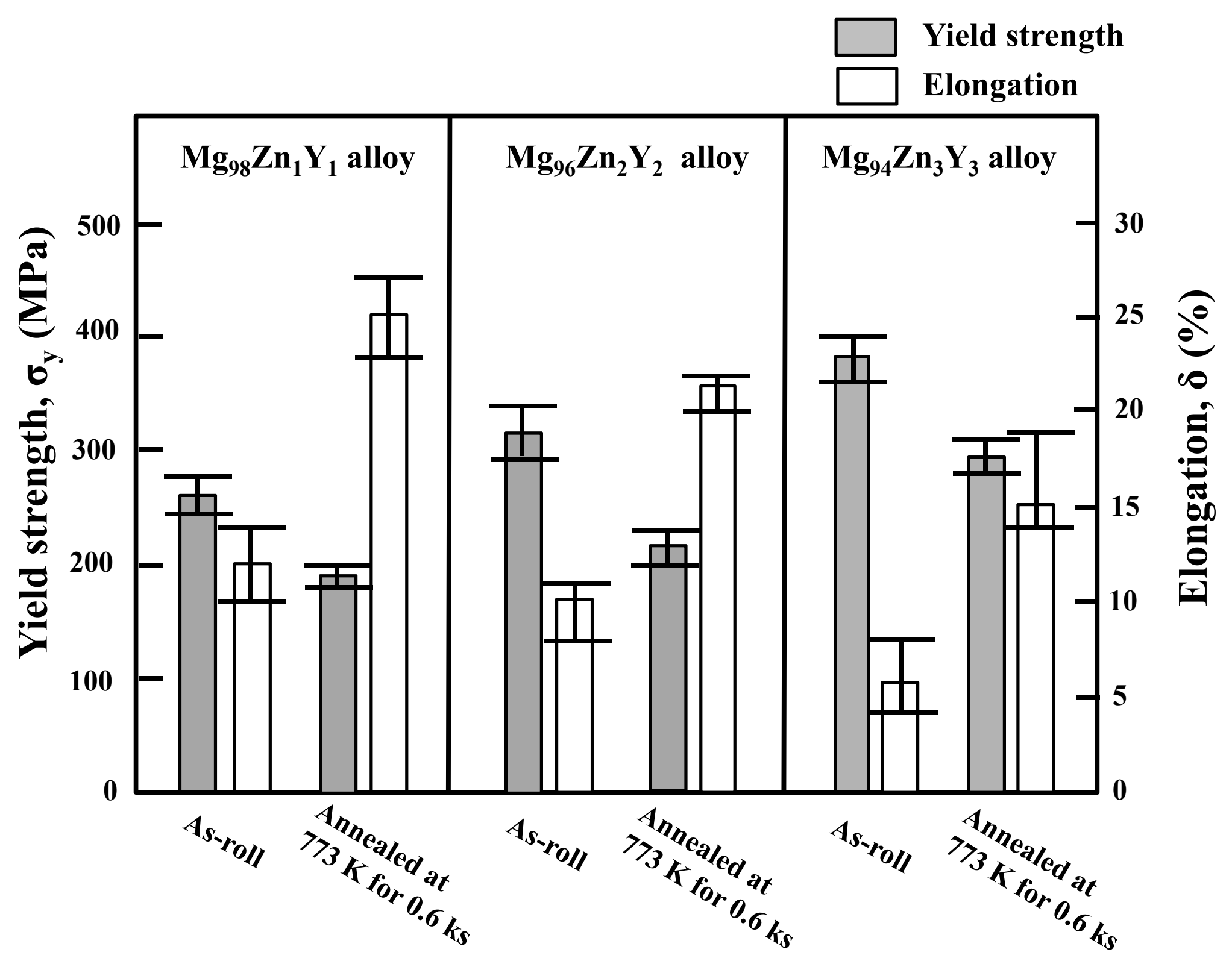

Figure 9. Tensile property of the $\mathrm{Mg}_{98} \mathrm{Zn}_{1} \mathrm{Y}_{1^{-}}, \mathrm{Mg}_{96} \mathrm{Zn}_{2} \mathrm{Y}_{2^{-}}$, and $\mathrm{Mg}_{94} \mathrm{Zn}_{3} \mathrm{Y}_{3}-$ alloy sheets and their annealed states $(773 \mathrm{~K}$ for $0.6 \mathrm{ks})$ at room temperature. 


\begin{tabular}{|c|c|c|c|}
\hline$R / t$ & 2.2 & 3.3 & 3.8 \\
\hline AZ31-O sheet & & & \\
\hline $\begin{array}{l}\mathrm{Mg}_{98} \mathrm{Zn}_{1} \mathrm{Y}_{1} \text { alloy sheet } \\
\text { annealed at } 773 \mathrm{~K} 0.6 \mathrm{ks}\end{array}$ & & & \\
\hline $\begin{array}{l}\operatorname{Mg}_{96} \mathrm{Zn}_{2} \mathrm{Y}_{2} \text { alloy sheet } \\
\text { annealed at } 773 \mathrm{~K} 0.6 \mathrm{ks}\end{array}$ & & & \\
\hline
\end{tabular}

Figure 10. Appearance of the $\operatorname{Mg}_{98} \mathrm{Zn}_{1} \mathrm{Y}_{1^{-}}, \operatorname{Mg}_{96} \mathrm{Zn}_{2} \mathrm{Y}_{2}$-annealed sheets, and AZ31-O sheet after $V$-bending test with $R / t$ of 3.8, 3.3 and 2.2, respectively. After the $V$-bending test, cracks in bent sheets were observed as indicated by white allows. 


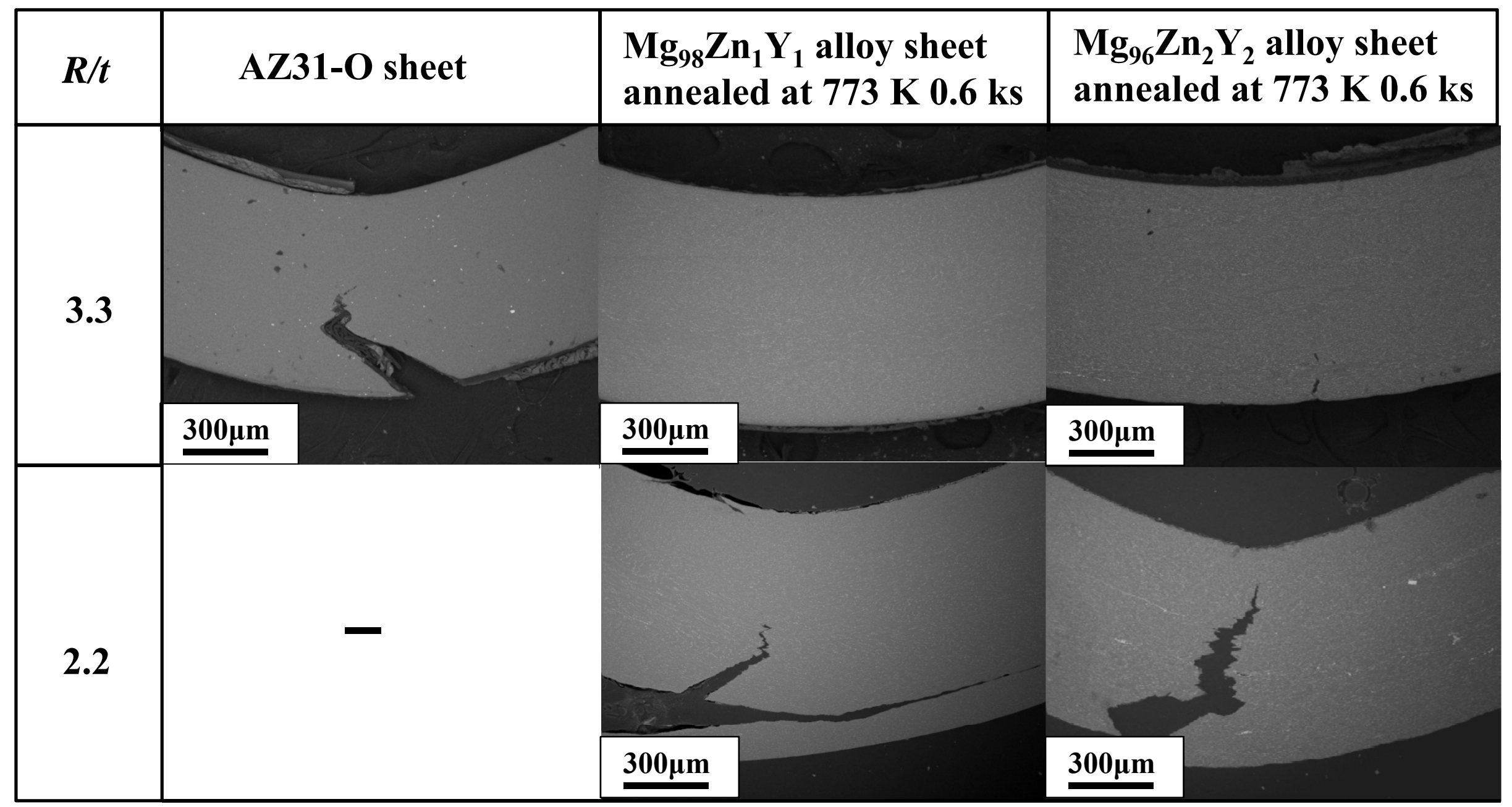

Figure 11. SEM images of bent $\mathrm{Mg}_{98} \mathrm{Zn}_{1} \mathrm{Y}_{1}-\mathrm{Mg}_{96} \mathrm{Zn}_{2} \mathrm{Y}_{2}$-annealed sheets, and AZ31-O sheet with $R / t$ of 3.3 and 2.2, respectively. 
Table 1. Ratio $R / t$ in $\mathrm{V}$-bending tests, where $R$ is the tip radius of punches and $t=0.8(\mathrm{~mm})$ is the sheet thickness.

\begin{tabular}{|c|c|c|c|c|}
\hline$R / \mathrm{mm}$ & 4.0 & 3.0 & 2.6 & 1.7 \\
\hline$R / t$ & 5.0 & 3.8 & 3.3 & 2.2 \\
\hline
\end{tabular}


Table 2. V-bending limit of Mg-Zn-Y alloy sheet, Mg-Zn-Y annealed sheet and AZ31-O sheet. After the V-bending test, cracks in bent sheets are recognized by visual inspection (Fig. 10) and using an SEM (Fig. 11). The (non)occurrence of a crack in a bent sheet is denoted by $(O) \times$.

\begin{tabular}{|c|c|c|c|c|}
\hline$R / t$ & 5.0 & 3.8 & 3.3 & 2.2 \\
\hline $\mathrm{Mg}_{98} \mathrm{Zn}_{1} \mathrm{Y}_{1}$ sheet & 0 & $x$ & $x$ & $x$ \\
\hline $\operatorname{Mg}_{96} Z_{n_{2}} Y_{2}$ sheet & 0 & $x$ & $x$ & $x$ \\
\hline $\mathrm{Mg}_{94} \mathrm{Zn}_{3} \mathbf{Y}_{3}$ sheet & $x$ & $x$ & $x$ & $x$ \\
\hline $\begin{array}{l}\mathrm{Mg}_{98} \mathrm{Zn}_{1} \mathrm{Y}_{1} \text { alloy sheet } \\
\text { annealed at } 773 \mathrm{~K} \text { for } 0.6 \mathrm{ks}\end{array}$ & 0 & 0 & 0 & $x$ \\
\hline $\begin{array}{l}\mathrm{Mg}_{96} \mathrm{Zn}_{2} \mathrm{Y}_{2} \text { alloy sheet } \\
\text { annealed at } 773 \mathrm{~K} \text { for } 0.6 \mathrm{ks}\end{array}$ & 0 & 0 & 0 & $x$ \\
\hline $\begin{array}{l}\mathrm{Mg}_{94} \mathrm{Zn}_{3} \mathrm{Y}_{3} \text { alloy sheet } \\
\text { annealed at } 773 \mathrm{~K} \text { for } 0.6 \mathrm{ks}\end{array}$ & 0 & $x$ & $x$ & $x$ \\
\hline AZ31-O sheet & 0 & 0 & $x$ & $x$ \\
\hline
\end{tabular}

